\title{
Study on the Vocational Happiness of Archivists in Colleges and Universities
}

\author{
Xiaoxiang $\mathrm{Li}^{1,}$ a , Tiantian $\mathrm{Gu}^{1, \mathrm{~b},{ }^{*}}$ and Xianhao $\mathrm{Yin}^{2, \mathrm{c}}$ \\ 1Zaozhuang University, Shandong 277160, China; \\ 2Shandong Zaozhuang downtown district people' congress (NPC), China. \\ a549916479@qq.com, *, b527576051@qq.com, c13256320808@163.com
}

Keywords: Archivists in colleges, Vocational happiness, Improvement.

\begin{abstract}
Based on the existing work status of college archivists, this paper analyzes the causes of the lack of college archivists' vocational happiness and explores the ways to improve the archivists' vocational happiness.
\end{abstract}

\section{Introduction}

Happiness is a continual satisfaction towards the current life as well as an emotion to maintain the existing state. Happiness is supported differently in different environments and time. Things that can make people happy now may not meet the public needs in the future. In my memory, people's requests for happiness constantly change: first, they have enough to eat; and then they want to eat well; next, they want to make more money and improve the living standards to pursue better life. Likewise, the happiness required and felt by new college archivists is also different from that of those college archivists who have worked for several years[1].

\section{Vocational Happiness of College Archivists}

Vocational happiness means a continual happy experience obtained by the subject when he or she is working: namely, the needs are satisfied, the potentials are fulfilled, and the capability gets enhanced. College archivists are different from college teachers but they are also connected with each other. On campus, college archivists are called teachers by students and their colleagues, but the address of "teachers" are different from those teachers who give lessons to students. The teaching profession doesn't necessarily bring people happiness, and the happiness of teachers mainly comes from the active creation and the role-play experience while he is teaching. Compared with common teachers, college archivists are more likely to lack the vocational happiness. If archivists lack the vocational happiness, it will influence both their living standards and the filing management.

\section{Causes of the Lack of Archivists' Vocational Happiness}

\subsection{Restrictions From the Traditional Requirements Towards Archivists}

The archival work has all along been least focused on by leaders. However, strict requirements are set for the archivists, and they are required to be dedicated and selfless. Moreover, their salary is rather unsatisfactory. All of these have brought archivists under great pressure. Most of archivists are from average families and they need to raise their families with their salaries, so they care much about their pay against the work. In particular, archivists tend to be young nowadays. They have distinct characteristics and prefer a relatively free working environment. They work hard with great enthusiasm at first, but they may have negative attitudes towards archival management when the working enthusiasm fades. It severely influences the efficient archival management as well as archivists' vocational happiness.

\subsection{Lower Social Status}

Colleges and universities focus more on teaching and scientific research, and the archival work is less recognized. Therefore, archivists are long marginalized and are humble in status, so it is common 
that they are looked down upon by other teaching staffs and aren't respected. In handling the material reception, archivists are sometimes complained, teased and abused by other teachers because the archival work must comply with a set of strict standards. It is caused by the long-term misunderstanding of the archival work. Moreover, the archival work always lacks the focus of the affiliated department leader. In daily work, people often think that it is so easy to do the archival management and that anyone is capable of the archival management. Thus, other work is given priority to in the department, while the archival work is put in the last pace. The lack of college archivists' vocational happiness is caused by the misunderstanding of colleagues, the less focus of leaders and other various pressures.

\subsection{Poor Work Environment and Loneliness}

Archival materials are confidential and very important, so they are generally managed in accordance with rather strict preservation conditions: the 24-hour supervisory video recording is made to ensure the safety of archival materials and the enclosed place is chosen to reduce the harm of archival materials. However, the enclosed environment and the continual video recording fail to protect the privacy of archivists. In addition, archivists are more likely to feel lonely because of lacking the communication with the outer world, and it is also difficult for archivists to tolerate the long-term repetitive work[2].

\subsection{Stereotypical Working Form and Heavy Working Pressure}

The archival work is clearly defined and it includes the collection, identification and sort out of archival materials, the look-up, borrowing and transmission of archival materials, etc. The daily work is very stereotypical without any fresh things, making archivists less flexible and it difficult to change the working habits. Meanwhile, it is not conducive to the future work. In addition, there are a lot of teaching staffs, so the archival materials are varied in variety like performance evaluation materials, salary materials, reward materials, archival materials of newly employed teachers, and transfers of archives for teachers who work on the degree of $\mathrm{PhD}$, etc. However, only one archivist is responsible for the filing management. Stereotypical work and heavy working pressure keep reducing the vocational happiness of college archivists.

\subsection{Poor Working Environment and Personnel Allocation}

Archives are generally kept for a long time, so archivists' health is often influenced by bacteria, mycete, and virus of archives. Meanwhile, a lot of modern office equipment like photocopier, printers and scanners also produce a lot of electronic pollution in the archive room. With the development of scientific technology and archives informatization, great changes have taken place in the patterns and content of the archival work. However, many leaders and personnel departments still treat the archival work as before, and they think that those who could handle the common office work are qualified for the archives management, let alone those informatization talents and management talents employed in the archival department of colleges and universities[3].

\subsection{Few Opportunities for Further Education And Promotion}

In colleges and universities, the staffs that teach and work on the scientific research are valued, so a lot of further education opportunities are offered to them. However, the administrative staffs are allocated more work but less cultivated in colleges and universities. And very few opportunities are offered to archivists for targeted further education and training. Archivists could not improve the working quality through training and further education, so they improved themselves through self-learning. Compared with other administrative staffs in colleges, the features of the archival work, namely stereotypical and not innovated, make it difficult for them to stand out. Moreover, there are limited means for them to improve their ability and develop themselves. Thus, the job transfer becomes a way for promotion. For those archivists who are unable to transfer jobs or get promoted, they have to accept the current working status and muddle along. 


\section{Ways to Improve the Vocational Happiness of College Archivists}

\subsection{Increase Leaders' Attention and Archivists’ Pay and Welfare}

Like the saying "A gentleman is ready to die for his bosom friends", if college leaders attach importance to the archival work, the archivists will also feel respected. Moreover, some incentive systems for archival management should be set to motivate archival staffs besides the basic scientific research reward, teaching reward, etc.

\subsection{Provide Balanced and Harmonious Development Opportunities}

Archivists are regularly trained and offered more opportunities for further learning. Meanwhile, the advanced scientific technology is employed to effectively reduce the pressure of archivists, improve their professional skills and strengthen their working capability. In addition, the promotion means similar to those of teaching and scientific research staffs are offered to increase the working enthusiasm of archivists and improve their vocational happiness.

\subsection{Expand the Scope of Interpersonal Communication}

Importance should be attached to develop the interpersonal relationships of archivists and their self-management ability. Positive energy is added to their work and life, and some interactive work should be set to increase opportunities for them to communicate with other colleagues. Meanwhile, mutual cooperation should be emphasized in the work to reduce the loneliness from the enclosed working atmosphere as well as to create a friendly and harmonious working relationship circle.

\section{Summary}

It is a long way to pursue happiness. Only if college administrators attach importance to the happiness of archivists and care more about archivists, the vocational happiness of archivists could be promoted and the archival work of colleges could be better, making the whole college administration strive for further development.

\section{References}

[1]. Mei Zhang. "E R G" Theory and professional happiness increase file. Lantai world. (2015) No.11, p.55-57.

[2]. Xiaoxiang Li, Xianhao Yin, Tiantian Gu. A brief analysis of archives management culture cultivation in colleges and universities.3rd international conference on management science and innovative education. Jinan, China, October 14-15 2017, p.449-452

[3]. Xiumei Zeng. On the professional happiness of the archivists in Colleges and Universities. Journal of Hubei Correspondence University. Vol. 24 (2011) No. 24, p. 34-35. 